\title{
Lysergide Measurement
}

National Cancer Institute

\section{Source}

National Cancer Institute. Lysergide Measurement. NCI Thesaurus. Code C75354.

The determination of the amount of lysergide (LSD) present in a sample. 